\title{
Quality of Laryngoscopic View and Rapidity of Development of Intubating Conditions after Atracurium, Vecuronium and Rocuronium: A Randomized Controlled Study
}

\author{
Manasij Mitra ${ }^{1}$, Abhishek Nag${ }^{2}$, Tanmoy Ganguly ${ }^{3}$, Sandeep Kumar Kar ${ }^{3 *}$ and Santi Lahiri ${ }^{1}$ \\ ${ }^{1}$ Department of Anaesthesiology, MGM Medical College, Kishanganj, India \\ ${ }^{2}$ Subham Hospital and Diagnostic Centre, Coochbehar, India \\ ${ }^{3}$ Department of Cardiac Anesthesiology, Institute of Postgraduate Medical Education and Research, Kolkata, India
}

\begin{abstract}
Introduction: The choice of muscle relaxant for endotracheal intubation may be straightforward in selective cases, but in most patients, who are otherwise uncomplicated, poses a dilemma among anesthesiologists and intensivists. The authors examined the most commonly used muscle relaxants (Vecuronium, atracurium and rocuronium) in equipotent doses and compared the most vital parameters, i.e., rapidity of development of clinically acceptable intubating condition and quality of laryngoscopic view.
\end{abstract}

Method: 150 adult patients of 18 to $50 \mathrm{y}$ of age were recruited randomly into 3 equal groups having 50 patients $(n=50)$ in each and equipotent dose of vecuronium, atracurium and rocuronium was administered. Endotracheal intubations were attempted every 30 seconds till excellent or good intubating conditions were achieved upto a maximum of $240 \mathrm{~s}$. The available data were analyzed statistically.

Results: The three study groups were comparable in terms of the demographic characteristics. The quality of intubating condition was rated significantly better with Rocuronium than with Vecuronium and Atracurium. Time required to achieve successful intubation was also significantly less with rocuronium than with Vecuronium (107.48 \pm $1.98^{*} 6.583 \mathrm{~s}$ vs. $\left.165.46 \pm 1.98^{*} 6.790 \mathrm{~s}\right)$ and Atracurium $\left(107.48 \pm 1.98^{*} 6.583 \mathrm{~s}\right.$ vs. $\left.195.43 \pm 1.98^{*} 6.583 \mathrm{~s}\right)$. Excellent laryngoscopic condition was found in more patients with rocuronium at 60 and $90 \mathrm{~s}$ and number of successful intubation was also higher.

Conclusion: Therefore, the study confirms that rocuronium produces clinically acceptable intubating condition earlier than the other two drugs and the quality of intubating condition is better in terms of laryngoscopic view.

Keywords: Muscle relaxants; Laryngoscopy; Intubating conditions; Rocuronium; Atracurium; Vecuronium

\section{Introduction}

From time immemorial the quest for an ideal anesthetic agent considered as the ultimate goal in anesthesia research. Scientists and chemists experimented over innumerable drugs and chemicals to find an agent which can provide sedation, analgesia, amnesia, muscle relaxation and loss of reflex response without any hemodynamic instability or undue adverse effect but failed to establish a single drug as a sole remedy of surgical stress. Modern anesthesia practice involves use of multiple drugs, e.g., sedatives, neuromuscular blockers (NMBs), analgesics etc., to achieve and maintain adequate plane of anesthesia during surgery. Among NMBs currently three agents very commonly used in the anesthesia practice, namely: atracurium, vecuronium and rocuronium. All these three drugs are intermediate acting nondepolarising neuromuscular blockers with unique advantages and disadvantages which guides their use in selective cases (Like atracurium or cisatracurium in renal or hepatic insufficiency owing to its liver or kidney independent unique metabolism: Hofmann elimination and nonspecific ester hydrolysis) [1-5]. But for general purpose, the ideal and best neuromuscular blocker is still to be investigated. For surgery under general anesthesia, maximum muscle relaxation is required during laryngoscopy and intubation. Therefore the neuromuscular blockers are usually judged in terms of their ability to produce ideal intubating conditions as well as quality of muscle relaxation after a specified time period.

In this background, the aims of this study were aimed to evaluate the quality and speed of development of clinically acceptable tracheal intubating conditions after administration of equipotent doses of Vecuronium, Atracurium and Rocuronium and to compare the timing of achievement of successful intubation in adults after administration of equipotent doses of the three drugs.

\section{Patients and Methods}

After obtaining research approval from Institutional research oversight committee and informed written consent from the patients, this randomized double blind study was conducted on 150 patients between 18 to $50 \mathrm{y}$ of age (Table 1), ASA physical status I and II posted for surgery under general anesthesia. Patients with anticipated difficult intubation, refused consent, contraindication to any drug under study (e.g., hepatic or renal insufficiency), any neuromuscular disorder, dyselectrolytemia, pregnancy or patients receiving drugs influencing neuromuscular transmission were sorted out in preoperative clinic and excluded. Patients were recruited to three groups according to

*Corresponding author: Dr. Sandeep Kumar Kar, Assistant Professor, Department of Cardiac Anaesthesiology, Institute of Postgraduate Medical Education and Research, Kolkata, India, Tel: +919477234900; E-mail: sndpkar@ yahoo.co.in

Received March 08, 2016; Accepted April 05, 2016; Published April 12, 2016

Citation: Mitra M, Nag A, Ganguly T, Kar SK, Lahiri S (2016) Quality of Laryngoscopic View and Rapidity of Development of Intubating Conditions after Atracurium, Vecuronium and Rocuronium: A Randomized Controlled Study. J Bioequiv Availab 8: 128-133. doi:10.4172/jbb.1000282

Copyright: ( 2016 Mitra M, et al. This is an open-access article distributed under the terms of the Creative Commons Attribution License, which permits unrestricted use, distribution, and reproduction in any medium, provided the original author and source are credited. 


\begin{tabular}{|l|c|l|}
\hline Drugs & ED 95 & $\begin{array}{l}\text { Doses considered for intubation, i.e., } \\
\text { 2 X ED95 }\end{array}$ \\
\hline Vecuronium [7-12] & $0.05 \mathrm{mg} / \mathrm{kg}$ & $0.1 \mathrm{mg} / \mathrm{kg}$ \\
\hline Atracurium [12-15] & $0.23 \mathrm{mg} / \mathrm{kg}$ & $0.25 \mathrm{mg} / \mathrm{kg}$ \\
\hline Rocuronium [7,16-20] & $0.3 \mathrm{mg} / \mathrm{kg}$ & $0.6 \mathrm{mg} / \mathrm{kg}$ \\
\hline
\end{tabular}

Table 1: Neuromuscular blockers: ED 95 values [6]

a computer generated randomization chart. Each group included 50 patients. Group A received $0.1 \mathrm{mg} / \mathrm{kg}$ vecuronium, group B received $0.5 \mathrm{mg} / \mathrm{kg}$ Atracurium and group $\mathrm{C}$ received $0.6 \mathrm{mg} / \mathrm{kg}$ rocuronium intravenous bolus as equipotent intubating dose of neuromuscular blocker.

After the patient was received in operating room, documents were checked, a brief examination was done and monitors were attached. Before intubation, ECG, pulse oxymetry, non-invasive blood pressure was monitored and after intubation end tidal carbon dioxide was also monitored. All patients were preoxygenated for $5 \mathrm{~min}$ and received glycopyrrolate $(0.2 \mathrm{mg})$, fentanyl $(2 \mu \mathrm{g} / \mathrm{kg})$, ondansetron $(4 \mathrm{mg}) 5 \mathrm{~min}$ before induction. Propofol $(2 \mathrm{mg} / \mathrm{kg})$ was used as induction agent. After the patient was induced, equipotent dose of neuromuscular blocker was introduced to the patients according to their randomization group as described earlier

The time of administration of neuromuscular blockers were noted. Endotracheal intubations were attempted by experienced anesthesiologist using cuffed polyvinylchloride endotracheal tubes [sizes appropriate for the age and the body structure]. The first intubation attempt was made at $60 \mathrm{~s}$, after administration of relaxant. Intubation conditions were scored as excellent, good or poor based on laryngoscopy [jaw relaxation], vocal cords position and movements and movement of limbs and coughing in response to intubation and/ or cuff inflation using the scoring systems proposed by Viby-Mogensen [21] (Tables 2 and 3). Least achieved score in any of the variables would determine the score of tracheal intubating conditions.

Endotracheal intubation was not performed until intubating conditions had been assessed to be excellent at the end of $60 \mathrm{~s}$ or 90 $\mathrm{s}$ and excellent or good at the end of $120 \mathrm{~s}$. Subsequent attempts were done at 30 seconds interval at $90 \mathrm{~s}, 120 \mathrm{~s}$ and the last attempt was made at $240 \mathrm{~s}$ until the intubation could be achieved with acceptable ease and the time of successful intubation was noted. Patients who did not achieve acceptable intubating conditions even at $240 \mathrm{~s}$ were managed with additional boluses of muscle relaxant and number of such patients were also noted. The study ended after successful intubation was achieved.

A difficult airway cart with instruments and devices for management of difficult airway was kept ready to combat emergency situation. The neuromuscular blockers were prepared by an anesthesiologist not involved in patient management and marked as 'Relaxant'. Intubation was done by an anesthesiologist unaware of the relaxant used. Data collection and analysis was performed by another anesthesiologist unaware of the group distribution.

For sample size calculation number of successful intubation at the end of $90 \mathrm{~s}$ was considered as the primary outcome measure. A pilot study was undertaken with 20 patients in each group and mean and standard deviation was measured. It was estimated that 45 subjects would be required per group in order to detect a difference of 10 patients with $80 \%$ power and $5 \%$ probability of type I error. Data was summarized as mean and standard deviation for parametric numerical variables and median and interquartile range for nonparametric numerical variables.

\begin{tabular}{|c|c|c|c|}
\hline Variables & Excellent & Good & Poor \\
\hline $\begin{array}{c}\text { Laryngoscopy } \\
\text { (Jaw relaxation) }\end{array}$ & $\begin{array}{c}\text { Easy (Fully } \\
\text { relaxed) }\end{array}$ & $\begin{array}{c}\text { Fair (Not fully } \\
\text { relaxed) }\end{array}$ & $\begin{array}{c}\text { Difficult } \\
\text { (Resistance) }\end{array}$ \\
\hline Vocal cord position & Abducted & Intermediate & Closed \\
\hline Vocal cord movement & None & Moving & Closing \\
\hline $\begin{array}{c}\text { Reaction to intubation AND/ } \\
\text { OR Cuff Inflation }\end{array}$ & None & Slight & Vigorous \\
\hline $\begin{array}{c}\text { Movements of limbs/ } \\
\text { Coughing }\end{array}$ & None & Diaphragm* & Sustained \\
\hline
\end{tabular}

*'diaphragm' indicates slight diaphragmatic movements only

Table 2: Endotracheal intubating condition score [21].

\begin{tabular}{|l|l|}
\hline Airway Examination Component & Anticipated difficult intubation \\
\hline $\begin{array}{l}\text { Length of upper incisors } \\
\text { mandiationship of maxillary and } \\
\text { jaw closure }\end{array}$ & $\begin{array}{l}\text { Relatively long } \\
\text { Prominent "overbite" (maxillary incisors } \\
\text { anterior to mandibular incisors) }\end{array}$ \\
\hline $\begin{array}{l}\text { Relationship of maxillary and } \\
\text { mandibular incisors during voluntary } \\
\text { protrusion of mandible }\end{array}$ & $\begin{array}{l}\text { Patient cannot bring mandibular } \\
\text { incisors anterior to (in front of) maxillary } \\
\text { incisors }\end{array}$ \\
\hline Interincisor distance & Less than $3 \mathrm{~cm}$ \\
\hline Visibility of uvula & $\begin{array}{l}\text { Not visible when tongue is protruded } \\
\text { with patient in sitting position (e.g., } \\
\text { Mallampati class>2) }\end{array}$ \\
\hline Shape of palate & Highly arched or very narrow \\
\hline Compliance of mandibular space & $\begin{array}{l}\text { Stiff, indurated, occupied by mass, or } \\
\text { non-resilient }\end{array}$ \\
\hline Thyromental distance & Less than three ordinary finger breadths \\
\hline Length of neck & Short \\
\hline Thickness of neck & Thick \\
\hline Range of motion of head and neck & $\begin{array}{l}\text { Patient cannot touch tip of chin to chest } \\
\text { or cannot extend neck }\end{array}$ \\
\hline
\end{tabular}

Guided by Practice Guidelines for Management of the Difficult Airway; An Updated Report by the American Society of Anesthesiologists Task Force on Management of the Difficult Airway [22]

Table 3: Anticipated difficult airway.

Counts and percentages were used for categorical variables. Parametric and nonparametric distribution was differentiated by KolmogorovSmirnoff Goodness of fit test. Numerical variables between groups compared by One-Way ANOVA. Categorical variables were compared by Chi-square test for post hoc comparison Tukey's test was applied (Figure 1).

\section{Results and Analysis}

150 patients were enrolled for the study and randomized to three groups of 50 patients each $(\mathrm{n}=50)$. Group A received $0.1 \mathrm{mg} / \mathrm{kg}$ of Vecuronium, group B $(\mathrm{n}=50)$, received $0.5 \mathrm{mg} / \mathrm{kg}$ of Atracurium and group $C(n=50)$, received $0.6 \mathrm{mg} / \mathrm{kg}$ of Rocuronium as intubating dose. Demographic variables, namely age, body weight and gender distribution compared between the groups and revealed no significant differences ( $\mathrm{p}$ value $0.585,0.092$ and 0.861 respectively) (Table 4).

The time required for successful intubation was compared between the groups and revealed mean intubation time in Group C (107.48 \pm $1.98 \mathrm{~s})$ was significantly lower than in A $(165.46 \pm 1.98 \mathrm{~s})$ and group $\mathrm{B}(195.43 \mathrm{sec} \pm 1.98 \mathrm{~s})$ [One-Way ANOVA test for numerical values; $\mathrm{p}<0.001$ ] [Mean \pm Standard deviation]. When the intubation times between any two individual groups were compared by Tukey's test for post-hoc comparison, the data showed that the intubation times in Group C was significantly different from those in Group A and Group $B$ [p $<0.001]$ (Figure 2).

Numbers of successful intubation at $60 \mathrm{~s}, 90 \mathrm{~s}$ and $120 \mathrm{~s}$ were 
Citation: Mitra M, Nag A, Ganguly T, Kar SK, Lahiri S (2016) Quality of Laryngoscopic View and Rapidity of Development of Intubating Conditions after Atracurium, Vecuronium and Rocuronium: A Randomized Controlled Study. J Bioequiv Availab 8: 128-133. doi:10.4172/jbb.1000282

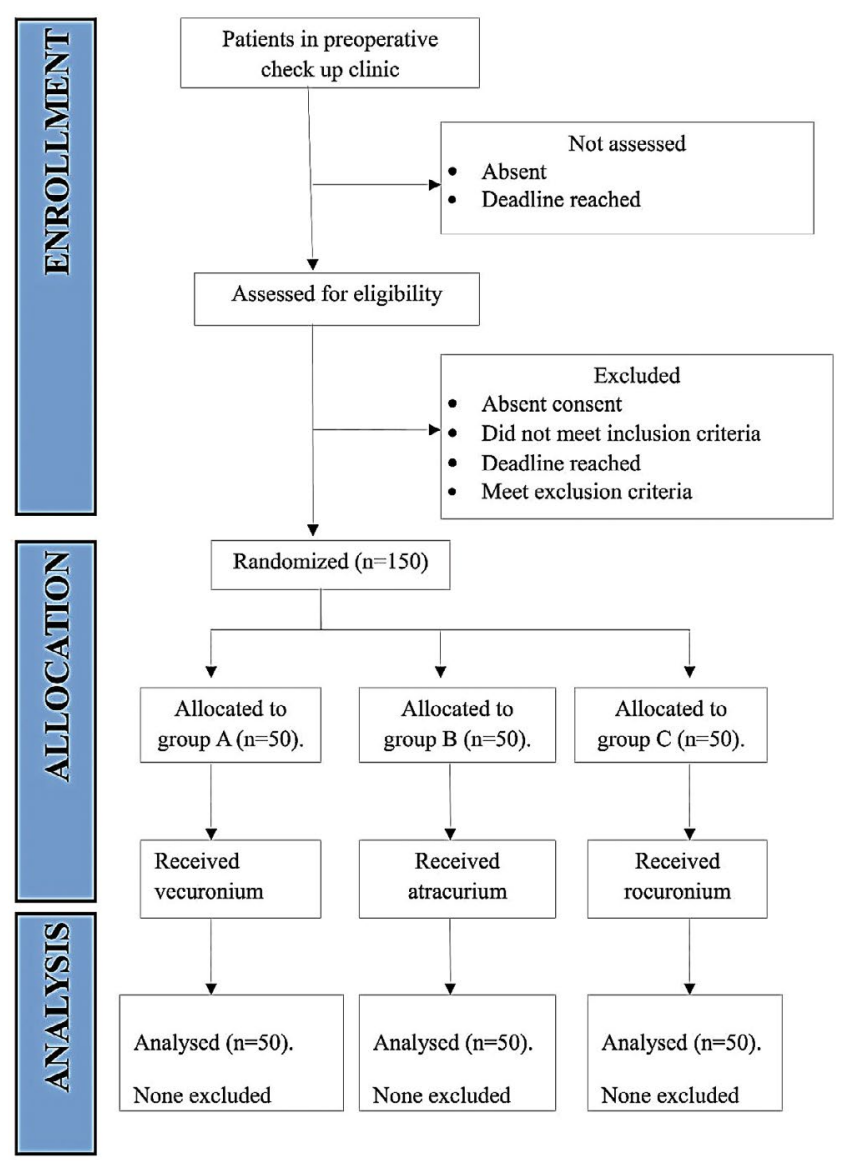

Figure 1: Flow chart (Consort diagram).

\begin{tabular}{|l|l|l|l|l|}
\hline & $\begin{array}{l}\text { Group A (n=50) } \\
\text { [Vecuronium] }\end{array}$ & $\begin{array}{l}\text { Group B (n=50) } \\
\text { [Atracurium] }\end{array}$ & $\begin{array}{l}\text { Group C (n=50) } \\
\text { [Rocuronium] }\end{array}$ & P value \\
\hline Age (Years) & $31.12 \pm 6.08$ & $29.89 \pm 5.84$ & $30.14 \pm 6.62$ & $0.585^{\mathrm{A}}$ \\
\hline $\begin{array}{l}\text { Body weight } \\
\text { (Kg) }\end{array}$ & $54.16 \pm 11.32$ & $49.62 \pm 9.35$ & $51.16 \pm 10.24$ & $0.092^{\mathrm{A}}$ \\
\hline $\begin{array}{l}\text { Gender [M/F } \\
\text { (\%)] }\end{array}$ & $35 / 15(70 \% / 30 \%)$ & $\begin{array}{l}36 / 12 \\
(74.47 \% / 25.53 \%)\end{array}$ & $37 / 13(74 \% / 26 \%)$ & $0.861^{\mathrm{B}}$ \\
\hline
\end{tabular}

A. One way ANOVA (Significant if $p$ value $<0.05$ )

B. Chi-Square test 2 sided (Significant if $p$ value $<0.05$ )

Table 4: Demography.

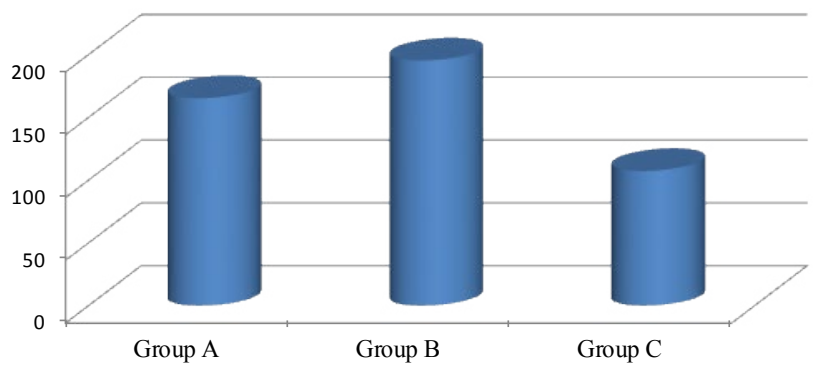

Group A: Vecuronium

Group B: Atracurium

Group C: Rocuronium

Figure 2: Time required for successful intubation. compared between the groups by Chi square test and significant differences were found between the groups. Individual groups, when compared with each other, it revealed Group C was significantly different from Group A and B [2-sided p value $<0.001$ ] and Group A and Group B are also significantly different [2-sided $\mathrm{p}$ value $=0.002]$. Number of successful intubation is more in group C after 60 and $90 \mathrm{~s}$ than other two groups (Figure 3).

The quality of intubating condition was compared between the groups after $1 \mathrm{~min}$ at $30 \mathrm{~s}$ interval up to $2 \mathrm{~min}$ and categorized as excellent, good and poor. In group A, excellent intubating conditions were developed in 22 patients. All other patients in group A developed good intubating conditions by $120 \mathrm{~s}$. Most of the patients developed poor intubating conditions at the end of $1 \mathrm{~min}$. The quality was mostly poor after $1 \mathrm{~min}$ and good after 60 and $90 \mathrm{~s}$ (Figure 4).

In group B, excellent intubating conditions were developed only in 16 patients after intubating dose and all of them developed excellent

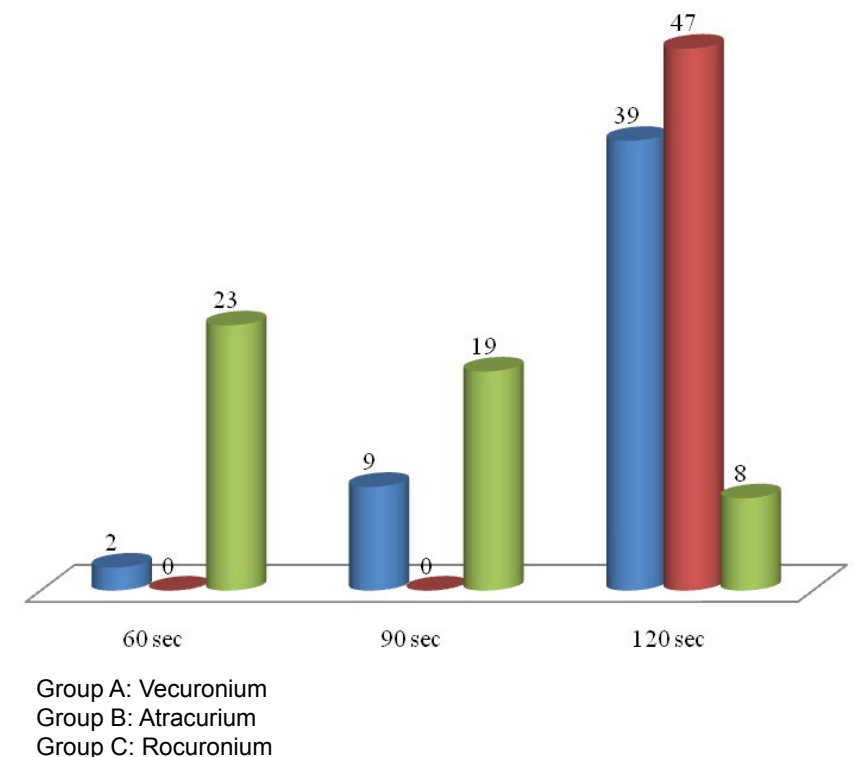

Figure 3: Number of successful intubations after $60 \mathrm{~s}, 90 \mathrm{~s}$ and $120 \mathrm{~s}$.

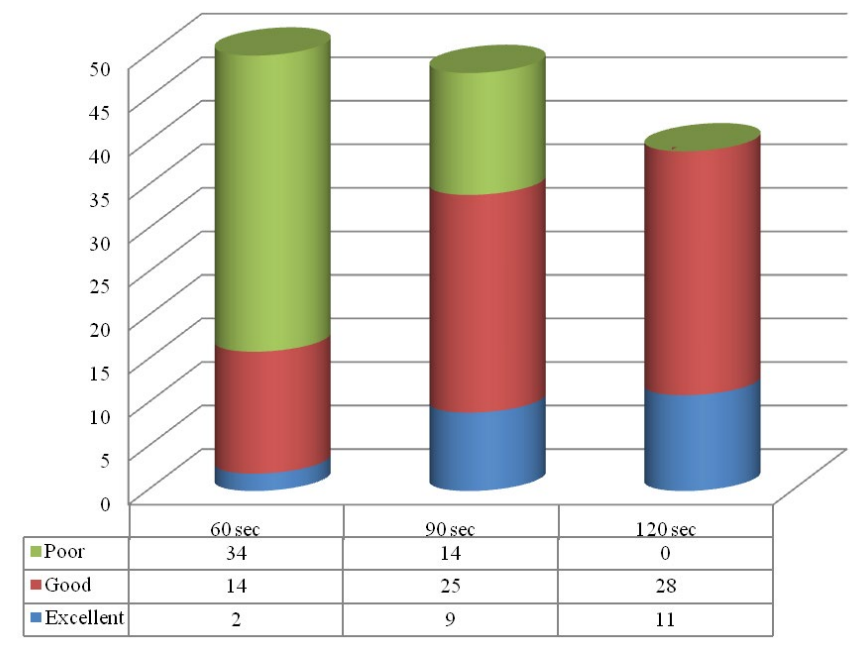

Figure 4: Quality of intubating condition in group A [Vecuronium]. 
Citation: Mitra M, Nag A, Ganguly T, Kar SK, Lahiri S (2016) Quality of Laryngoscopic View and Rapidity of Development of Intubating Conditions after Atracurium, Vecuronium and Rocuronium: A Randomized Controlled Study. J Bioequiv Availab 8: 128-133. doi:10.4172/jbb.1000282

intubating condition after $120 \mathrm{~s}$. Intubating condition was mostly poor after $60 \mathrm{~s}$. Three patients did not develop good intubating conditions even after $240 \mathrm{~s}$ and required additional anesthetics and neuromuscular blocker (Figure 5).

Whereas in group $\mathrm{C}$ excellent intubating condition obtained in 50 patients and of which 23 were reached within $60 \mathrm{~s}$ (Figure 6).

\section{Discussion}

The most accurate assessment of potency of a neuromuscular blocking drug is aided by its ability to depress twitch height [5-17]. The drug dose relationship is established by calculating the required dose of neuromuscular blocking agent to produce a certain response. The dose required to produce $50 \%, 90 \%$, or $95 \%$ depression of twitch height is commonly expressed as ED50, ED90, and ED95 of a drug and it is considered as a measurement of potency. Therefore to compare between neuromuscular blockers one must use the dose which is same multiplier of ED50 or ED95 [6,7,20,23-33]. In this study, the authors used twice the ED 95 dose for intubation in all three groups. The ED 95 values of the three muscle ralaxants with intubating dose is depicted in Table 1.

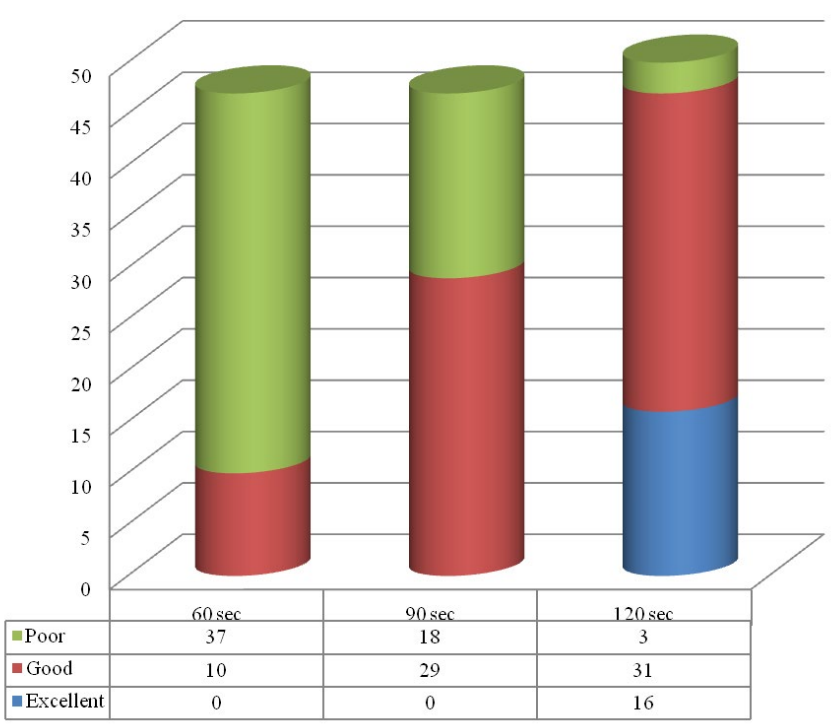

Figure 5: Quality of intubating condition in group B [Atracurium].

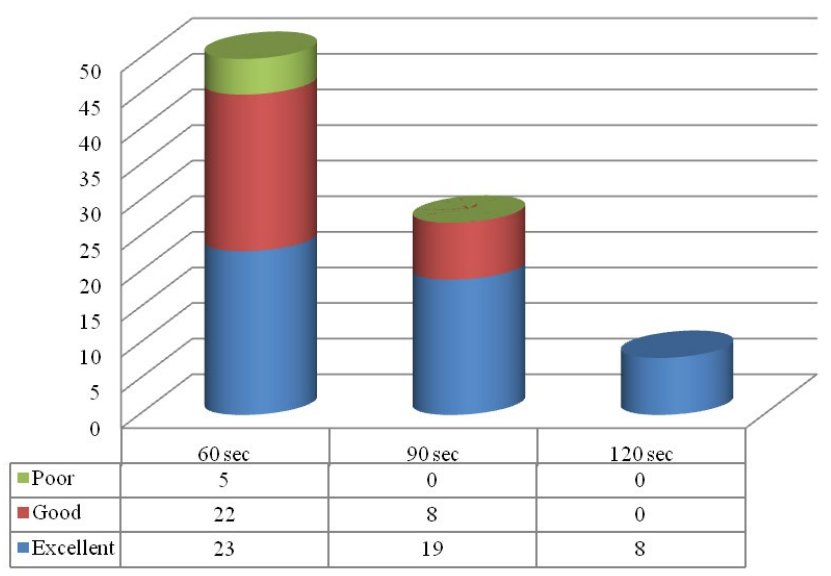

Figure 6: Quality of intubating condition in group B [Rocuronium].
Complete relaxation of the jaw, laryngeal and pharyngeal muscles, and diaphragm are needed for excellent intubating conditions and to reduce the risk of trauma. The response to intubation is a function of both muscular block and the level of anaesthesia. It is possible to intubate a patient with less-than-complete paralysis if a sufficient depth of anaesthesia is present [18]. The authors used same dose of other anesthetics to avoid this confounding. All inhalational anaesthetics have some amount of neuromuscular blocker property [19]. No inhalational anaesthetics and intravenous hypnotic or opioid drugs were used after administration of the neuromuscular blocker. Therefore, it may be supposed that the improvement of intubating conditions results from the increasing neuromuscular block only, with no confounding effects of inhalation agents, opioids or hypnotics. In group C [Rocuronium group] 23 patients out of 50 achieved excellent intubating condition at the end of $60 \mathrm{~s}$, whereas of the 100 patients in the Vecuronium and Atracurium groups, only 4 could have their tracheas intubated $60 \mathrm{~s}$ after injection of the neuromuscular blocker, which signifies the faster onset of action with rocuronium.

The onset of neuromuscular block would be faster in centrally located muscles such as the diaphragm, facial, laryngeal, and jaw muscles than peripheral muscles such as the adductor policies. The diaphragm, eye muscles, and most laryngeal muscles are more resistant to non-depolarizing relaxants than are peripheral muscles [6]. The diaphragm is resistant to succinylcholine, though the laryngeal muscles are sensitive to it. The masseter muscle is relatively sensitive to both non-depolarizing and depolarizing relaxants. Furthermore, peripheral neuromuscular block was not complete at the time of successful intubation in most patients. In adults, a faster onset at the laryngeal muscle compared to the peripheral muscles was reported with Rocuronium [34], Vecuronium [35] and Atracurium [36]. Therefore, it can be accepted that, when conducting studies of intubating conditions, only frequent-interval intubation attempts, begun sufficiently early can reveal development of optimum laryngeal conditions. This is particularly true for fast-acting neuromuscular blockers, such as Rocuronium, where the peripherially assessed onset of neuromuscular block can give no exact indication of the moment when optimum laryngeal relaxation has first been achieved.

There were few studies where the onset of action of Atracurium was found to be earlier than Vecuronium as reported by [24]. But here in this study, the mean duration of successful intubation after Atracurium $(195.43 \mathrm{~s} \pm 1.98 \mathrm{~s})$ is longer than that of Vecuronium $(165.46 \mathrm{~s} \pm 1.98$ s). These discrepancies might be due to the different techniques of monitoring the neuromuscular blockade used (forced transducer, EMG, etc.) as well as due to the background anaesthetic used.

In most studies, evaluating intubating conditions after Atracurium or Vecuronium, potent inhaled anaesthetics were used during induction, and endotracheal intubation was not attempted until complete neuromuscular block was attained. The results of these studies compares well with the results of the present study. The quality of intubating conditions at the point of successful intubation was also rated better after Rocuronium than with Vecuronium and Atracurium, which matched with the results demonstrated in previous investigations in adults [37]. Vecuronium tended to be superior also to Atracurium, but this difference was not considered statistically significant. In adults, the onset of neuromuscular blockade at the adductor pollicis muscle after Rocuronium is more rapid compared to Vecuronium and Atracurium $[25,26]$ as described. These results match well with the results derived in the present study.

Bartkowski et al. [24] compared the onset, maximal neuromuscular 
Citation: Mitra M, Nag A, Ganguly T, Kar SK, Lahiri S (2016) Quality of Laryngoscopic View and Rapidity of Development of Intubating Conditions after Atracurium, Vecuronium and Rocuronium: A Randomized Controlled Study. J Bioequiv Availab 8: 128-133. doi:10.4172/jbb.1000282

block, and duration of rocuronium to atracurium and vecuronium during enflurane anesthesia and found significantly faster onset time with Rocuronium. They also found using equipotent doses, atracurium also had a shorter time to develop neuromuscular block than vecuronium. The authors found similar results.

In the atracurium group only 16 patients achieved excellent intubating condition at the end of $120 \mathrm{~s}$ and three patients did not reach adequate relaxation even after $240 \mathrm{~s}$. This indicates slower onset and poor quality of relaxation with atracurium than other two drugs. The author thus advocates against use of atracurium where rapid endotracheal intubation are intended such as in critical care settings.

The main limitation of the aforementioned study was the stress response after endotracheal intubation was not adequately addressed. Endotracheal intubation is considered as one of the most stressful procedures and multiple drugs are used to combat the stress related to this procedure of which muscle relaxants assume a crucial part. To assess the stress response, the clinician must address the hemodynamic and clinical parameters (Pulse, blood pressure, electrocardiographic abnormality, papillary changes, etc.) as well as the stress markers (including blood glucose, cortisol and other biomarkers). Another drawback of this study was, the drugs were tested in ideal condition in selected patients posted for elective surgery. For critically ill patients in intensive care units the organ functions (e.g., liver disease, renal failure, etc.) and blood biochemistry (e.g., acid base disturbances, dyselectrolytemias, etc.) are deranged and there is a possibility of altered pharmacokinetics and pharmacodynamics of these drugs. Reversibility of the neuromuscular blockade and duration of action were not addressed in this study. Further studies may be undertaken to consider these possibilities and address the situations $[38,39]$.

\section{Conclusion}

In conclusion, in the aforementioned study, after administration of equipotent doses of vecuronium, atracurium or rocuronium in patients, the speeds with which good intubating conditions were produced were quite different depending on the neuromuscular blocker used. There was more rapid development of clinically acceptable and of better quality intubating conditions after Rocuronium compared to both Vecuronium and Atracurium. So, Rocuronium may be a better choice than Atracurium and Vecuronium for intubation in perioperative as well as critical care settings.

\section{References}

1. Neill EA, Chapple DJ, Thompson CW (1983) Metabolism and kinetics of atracurium: An overview. Br J Anaesth 55 Suppl 1: 23S-25S.

2. Savarese JJ, Lien CA, Belmont MR, Wastila WB (1997) The clinical pharmacology of new benzylisoquinoline-diester compounds, with special consideration of cisatracurium and mivacurium. Anaesthesist 46: 840-849.

3. Kisor DF, Schmith VD, Wargin WA, Lien CA, Ornstein E, et al. (1996) Importance of the organ-independent elimination of cisatracurium. Anesth Analg 83: 10651071.

4. Ward S, Neill EA (1983) Pharmacokinetics of atracurium in acute hepatic failure (with acute renal failure). $\mathrm{Br} \mathrm{J}$ Anaesth 55: 1169-1172.

5. Vandenbrom RH, Wierda JM, Agoston S (1990) Pharmacokinetics and neuromuscular blocking effects of atracurium besylate and two of its metabolites in patients with normal and impaired renal function. Clin Pharmacokinet 19: 230-240.

6. Naguib M, Lien CA (2010) Pharmacology of Neuromuscular blockers and Their Antagonists. In: Miller RD (Eds) Miller's Anesthesia. $7^{\text {th }}($ Edn) Philadelphia: Churchill Livingstone, Elsevier Inc., USA.

7. Naguib M, Samarkandi AH, Bakhamees HS, Magboul MA, el-Bakry AK
(1995) Comparative potency of steroidal neuromuscular blocking drugs and isobolographic analysis of the interaction between rocuronium and other aminosteroids. Br J Anaesth 75: 37-42.

8. Lienhart A, Desnault $H$, Viars $P(1983)$ Determination of the dose-effect curve of vecuronium in anesthetized man. Ann Fr Anesth Reanim 2: 3-6.

9. Krieg N, Crul JF, Booij LH (1980) Relative potency of ORG NC 45, pancuronium alcuronium and tubocurarine in anaesthetized man. Br J Anaesth 52: 783-788.

10. Engbaek J, Ording H, Pedersen T, Viby-Mogensen J (1984) Dose-response relationships and neuromuscular blocking effects of vecuronium pancuronium during ketamine anaesthesia. $\mathrm{Br} J$ Anaesth 56: 953-957.

11. Ferres CJ, Mirakhur RK, Pandit SK, Clarke RS, Gibson FM (1984) Doseresponse studies with pancuronium, vecuronium and their combination. $\mathrm{Br} \mathrm{J}$ Clin Pharmacol 18: 947-950.

12. Black TE, Healy TE, Pugh ND, Kay B, Harper NJ, et al. (1985) Neuromuscular block: atracurium and vecuronium compared and combined. Eur J Anaesthesiol 2: $29-37$.

13. Savarese JJ, Lien CA, Belmont MR, Wastila WB (1997) The clinical pharmacology of new benzylisoquinoline-diester compounds, with special consideration of cisatracurium and mivacurium. Anaesthesist 46: 840-849.

14. Basta SJ, Ali HH, Savarese JJ, Sunder N, Gionfriddo M, et al. (1982) Clinical pharmacology of atracurium besylate (BW 33A): a new non-depolarizing muscle relaxant. Anesth Analg 61: 723-729.

15. Meretoja OA, Wirtavuori K (1989) Two-dose technique to create an individual dose-response curve for atracurium. Anesthesiology 70: 732-736.

16. Foldes FF, Nagashima H, Nguyen HD, Schiller WS, Mason MM, et al. (1991) The neuromuscular effects of ORG9426 in patients receiving balanced anesthesia. Anesthesiology 75: 191-196.

17. Taivainen T, Meretoja OA, Erkola O, Rautoma P, Juvakoski M (1996) Rocuronium in infants, children and adults during balanced anaesthesia Paediatr Anaesth 6: 271-275.

18. Mirakhur RK (1995) Dose-response and time-course of action of rocuronium bromide. Eur J Anaesthesiol Suppl 11: 23-25.

19. Naguib M, Samarkandi AH, Ammar A, Elfaqih SR, Al-Zahrani S, et al. (1998) Comparative clinical pharmacology of rocuronium, cisatracurium, and their combination. Anesthesiology 89: 1116-1124.

20. Booij LH, Knape HT (1991) The neuromuscular blocking effect of Org 9426. A new intermediately-acting steroidal non-depolarising muscle relaxant in man. Anaesthesia 46: 341-343.

21. Cooper R, Mirakhur RK, Clarke RS, Boules Z (1992) Comparison of intubating conditions after administration of Org 9246 (rocuronium) and suxamethonium. Br J Anaesth 69: 269-273.

22. Apfelbaum JL, Hagberg CA, Caplan RA, Blitt CD, Connis RT, et al. (2013) American society of anesthesiologists task force on management of the difficult airway. Practice guidelines for management of the difficult airway: An updated report by the American Society of Anesthesiologists Task Force on Management of the Difficult Airway. Anesthesiology 118: 251-270.

23. Shanks CA (1986) Pharmacokinetics of the non-depolarizing neuromuscular relaxants applied to calculation of bolus and infusion dosage regimens. Anesthesiology 64: 72-86.

24. Bartkowski RR, Witkowski TA, Azad S, Lessin J, Marr A (1993) Rocuronium onset of action: A comparison with atracurium and vecuronium. Anesth Analg 77: $574-578$.

25. Bevan DR, Fiset P, Balendran P, Law-Min JC, Ratcliffe A, et al. (1993) Pharmacodynamic behaviour of rocuronium in the elderly. Can J Anaesth 40: 127-132.

26. Weber S, Brandom BW, Powers DM, Sarner JB, Woelfel SK, et al (1988) Mivacurium chloride (BW B1090U)-induced neuromuscular blockade during nitrous oxide-isoflurane and nitrous oxide-narcotic anesthesia in adult surgical patients. Anesth Analg 67: 495-499.

27. Caldwell JE, Kitts JB, Heier T, Fahey MR, Lynam DP, et al. (1989) The doseresponse relationship of mivacurium chloride in humans during nitrous oxidefentanyl or nitrous oxide-enflurane anesthesia. Anesthesiology 70: 31-35. 
Citation: Mitra M, Nag A, Ganguly T, Kar SK, Lahiri S (2016) Quality of Laryngoscopic View and Rapidity of Development of Intubating Conditions after Atracurium, Vecuronium and Rocuronium: A Randomized Controlled Study. J Bioequiv Availab 8: 128-133. doi:10.4172/jbb.1000282

28. Diefenbach C, Mellinghoff H, Lynch J, Buzello W (1992) Mivacurium: doseresponse relationship and administration by repeated injection or infusion. Anesth Analg 74: 420-423.

29. Wierda JM, Beaufort AM, Kleef UW, Smeulers NJ, Agoston S, et al. (1994) Preliminary investigations of the clinical pharmacology of three short-acting non-depolarizing neuromuscular blocking agents, Org 9453, Org 9489 and Org 9487. Can J Anaesth 41: 213-220.

30. Kopman AF, Klewicka MM, Ghori K, Flores F, Neuman GG (2000) Doseresponse and onset/offset characteristics of rapacuronium. Anesthesiology 93 : 1017-1021.

31. Fuchs-Buder T, Claudius C, Skovgaard LT, Eriksson LI, Mirakhur RK, et al. (2007) Good clinical research practice in pharmacodynamic studies of neuromuscular blocking agents II: the Stockholm revision. Acta Anaesthesiol Scand 51: 789-808

32. Jerry A. Dorsch, Susan E. Dorsch (2006) Neuromuscular transmission monitoring. In Understanding Anesthesia Equipment, $5^{\text {th }}$ (Edn), Chapter 25, Philadelphia, Lippincott Williams \& Wilkins: 819.

33. Joseph P. Cravero, Zeev N (2006) KainPediatricAnesthesia: Anesthetic agents.
In Paul G Barash, Bruce F Cullen, Robert K Stoelting ; Clinical Anesthesiology $5^{\text {th }}($ Edn) Philadelphia, Lippincott Williams \& Wilkins: 1209-1212.

34. Meistelman C, Plaud B, Donati F (1992) Rocuronium (ORG 9426) neuromuscular blockade at the adductor muscles of the larynx and adductor pollicis in humans. Can J Anaesth 39: 665-669.

35. Donati F, Meistelman C, Plaud B (1991) Vecuronium neuromuscular blockade at the adductor muscles of the larynx and adductor pollicis. Anesthesiology 74 : 833-837.

36. Ungureanu D, Meistelman C, Frossard J, Donati F (1993) The orbicularis oculi and the adductor pollicis muscles as monitors of atracurium block of laryngeal muscles. Anesth Analg 77: 775-779.

37. Chetty MS, Pollard BL, Wilson A, Healy TE (1996) Rocuronium bromide in dental day case anaesthesia--a comparison with atracurium and vecuronium. Anaesth Intensive Care 24: 37-41.

38. Magorian T, Flannery KB, Miller RD (1993) Comparison of rocuronium succinylcholine and vecuronium for rapid-sequence induction of anesthesia in adult patients. Anesthesiology 79: 913-918.

39. De Mey JC, Debrock M, Rolly G (1994) Evaluation of the onset and intubation conditions of rocuronium bromide. Eur J Anaesthesiol Suppl 9: 37-40. 